\title{
DETERMINATION OF THE PERFORMANCES AND ADOPTION LEVELS OF SUNFLOWER CULTIVARS BASED ON RESISTANCE TO BROOMRAPE IN FARM CONDITIONS IN THRACE REGION
}

\author{
Semerci, A. ${ }^{1}$, Kaya, Y. ${ }^{1}$, Sahin, I. ${ }^{2}$ and Citak, N. ${ }^{2}$ \\ ${ }^{1}$ Trakya Agricultural Research Institute, 22100, Edirne, Turkey \\ ${ }^{2}$ Trakya Birlik, Edirne, Turkey
}

Received: April 10, 2010

Accepted: August 10, 2010

\begin{abstract}
SUMMARY
About $65 \%$ of sunflower production in Turkey, which is the world's $11^{\text {th }}$ largest producer of sunflower based on the FAO data, occurs in the Thrace region. The biggest problem in sunflower areas in the Thrace region is broomrape (Orobanche cernua L.). Three types of sunflower cultivars are planted in the region, namely hybrids genetically resistant to broomrape (GRH), nonresistant ones (NRH) and IMI (Imidazolinone) herbicide resistant ones (IMIH), which control both broomrape and key weeds in sunflower production. The adoption situation and the performances of these three sunflower hybrid types were studied in the research. The research data was obtained from 571 agricultural enterprises, which were determined based on the Stratified Random Sampling Method in the Thrace region. Sunflower is grown on $42 \%$ of the total cultivated land surveyed in the research and accounts for $23 \%$ of the total agricultural revenue. The adoption rate and degree of IMIH and GRH sunflower hybrids were calculated to be over $90 \%$. The highest yield $\left(1,915.10 \mathrm{~kg} \mathrm{ha}^{-1}\right)$ was obtained from GRH hybrids in the research areas. A high yielding potential and easier weed control are seen by the farmers as being among the most important factors for choosing a particular type of sunflower seed. Statistical differences were observed among the sunflower hybrid types based on seed yield, revenue, and seed amounts. The highest net profit was obtained from GRH hybrids in the study. Additionally, based on the results, NRH hybrids were found to be more profitable than IMI hybrids.
\end{abstract}

Key words: sunflower production, broomrape, revenue, adoption, yield, farmers' perception

\section{INTRODUCTION}

Vegetable oil originating from oil crops is one of the important sources of human nutrition. About twenty kinds of oil crops are produced in the world, and while soybean is the first-ranked oilseed in the world, sunflower is the main oil crop 
HELIA, 33, Nr. 53, p.p. 69-76, (2010)

in Turkey. Turkey has $2.04 \%$ of the world area planted to sunflower and accounts for $2.56 \%$ of the world sunflower production (FAO, 2009). The Turkish sunflower yield is $26 \%$ higher than the world sunflower yield. Sunflower is mainly produced in the Thrace region of Turkey, which accounts for $59.51 \%$ of the total acreage sown to sunflower in the country and is responsible for $62.04 \%$ of the country's total sunflower production (TUIK, 2009).

In the present study we first analyzed the plant production pattern of agricultural enterprises in the survey area, after which the importance of sunflower in the region was emphasized by calculating total agricultural income and the percentage contribution of sunflower to this amount. Three types of sunflower hybrids are planted in the Thrace region: those that are genetically resistant to broomrape (GRH), those that are non-resistant to the pathogen (NRH), and those that are resistant to IMI (Imidazolinone) herbicides. The adoption rate and performance of these three types of sunflower hybrids were studied in this piece of research.

Another aim of the research was to determine the total cost, net income (as net and gross profit), preference factors, and the adoption rate of sunflower hybrid groups planted in Thrace as the most important sunflower-growing region in Turkey.

\section{MATERIAL AND METHOD}

Research data were obtained from the project "The Determination of Efficiency of Subsidizing Policies and Productivity in Sunflower Production (TAGEM - 08/ARGE / 06)". The formula used for the sampling method in the research based on Neyman's method is given below (Yemane, 1967).

$$
\mathrm{n}=\frac{\sum(\mathrm{Nh} \mathrm{Sh})^{2}}{\mathrm{~N}^{2} \mathrm{D}^{2}+\Sigma \mathrm{Nh}(\mathrm{Sh})^{2}}
$$

The number of districts was determined as 53 (95\% confidence interval and $4 \%$ deviation of average), while the number of agricultural enterprises was 571 (95\% confidence interval and $1 \%$ deviation of average) using the above formula (Erkan and Cicek, 1996). The production costs of GRH, NRH and IMIH were determined based on the method explained below (Erkus and Demirci, 2007).

Total Gross Production Value (TGPV):

Yield $\left(\mathrm{kg} \mathrm{ha}^{-1}\right) \times$ product sale price (including subsidies)

\section{Net Profit:}

TGPV - (variable expenses + constant expenses),

\section{Gross Profit:}

TGPV - variable expenses

\section{Variable Expenses:}

Soil preparation + planting + fertilizing + harvest + transportation + seed + fertilizer + chemicals 
Constant (Fixed) Expenses:

Land rent + other costs + capital interest + administrative expenses

Other Expenses:

Total costs $\times 0.05$

Capital Interest:

(Total costs + other expenses + land rent) $\times$ (Interest rate of production period $\times(0.07))$

\section{Administrative Expenses:}

(Total costs + other expenses + land rent) $\times 0.03$

The adoption rate was calculated as the number of farmers who adopted the sunflower cultivar divided by the total number of sunflower farmers; the adoption degree was the rate of the sunflower cultivar in proportion to the total sunflower area; and the adoption intensity was obtained by multiplying the adoption degree with the adoption degree in the research (Shideed and El Mourid, 2005; Mazid et al., 2009).

One-way ANOVA was used to determine statistical differences among sunflower cultivars based on seed yield, revenue, and seed amount per ha. The SPSS program was used for statistical analysis and the "Tukey HSD Test" was used to determine the differences among groups (Ural and Kilic, 2006; Green et al., 2000).

\section{RESULTS AND DISCUSSION}

\section{Areas planted to sunflower}

A total of 5,349.75 ha of sunflower were planted in the research area and the rate was $42.73 \%$ of the area studied. The rate varied between 40.74 and $46.53 \%$ among the provinces in the region.

\section{Agricultural revenue}

The total agricultural revenue in 2009 was calculated as 23 million US\$ in all 571 farm enterprises, and $86.83 \%$ of this revenue was obtained from planned production. The rate of sunflower was $22.71 \%$ of plant production and $19.72 \%$ of total agricultural revenue.

\section{Plant production pattern}

Based on surveys in the research area, the most important crop was wheat (51.73\%), while sunflower was determined to be the second most important crop species, with $42.74 \%$ existing as the main rotation system in the region. Barley was third in importance in the research area, and rice was also found to be important, especially in irrigated areas in the Edirne province. 


\section{Sunflower production costs according to sunflower hybrid groups}

The average yield of sunflower was calculated to be $1,773.4 \mathrm{~kg} \mathrm{ha}^{-1}$ overall. The average production cost per ha was calculated to be 928.40 US\$ and the production cost per ton was calculated as 524 US\$. When all three sunflower group were evaluated, the highest gross revenue (656.88 $\mathrm{USS}^{-1} \mathrm{ha}^{-1}$ ) and net revenue (303.71 US\$ ha-1) were obtained from GRH cultivars. Sunflower production cost was calculated as $928.40 \mathrm{USS} \mathrm{ha}^{-1}$ and net profit was determined to be $210.71 \mathrm{USS} \mathrm{ha}^{-1}$ in the research. However, the highest production cost was also obtained from GRH cultivars (483.79 US\$ per ton) based on the average values of agricultural enterprises in the research area.

\section{Factors affecting farmers' selection of sunflower cultivars based on producer perception}

Most of the farmers (212, or $72 \%$ ) indicated that they chose IMIH cultivars due to the fact that they enabled easy control of weeds (Table 1). The other factors were resistance to broomrape (16.17\%) and higher yield potential (7.82\%).

Table 1: Reasons for choosing IMIH sunflower cultivars

\begin{tabular}{lcccccc}
\hline \multirow{2}{*}{ Reason } & \multicolumn{3}{c}{ Province } & \multicolumn{2}{c}{ Research } \\
\cline { 2 - 6 } & Edirne & Kirklareli & Tekirdag & Istanbul & Çanakkale & 0 \\
\hline Higher seed yield potential & 14 & 6 & 3 & 0 & 23 \\
Resistance to broomrape & 24 & 4 & 20 & 0 & 1 & 49 \\
Easy availability on the market & 0 & 0 & 0 & 1 & 1 & 2 \\
Easy weed control & 12 & 88 & 88 & 24 & 0 & 212 \\
Higher oil content & 0 & 3 & 1 & 0 & 1 & 5 \\
Other reasons & 0 & 0 & 3 & 0 & 0 & 3 \\
\hline
\end{tabular}

The farmers producing GRH cultivars indicated that the main reason why they chose these hybrids was because of them having higher yield potential (173 growers, or $43.36 \%$ ) and broomrape resistance (31.83\%) (Table 2). Another factor mentioned was higher oil content potential (16.54\%).

Table 2: Reasons for choosing GRH sunflower cultivars

\begin{tabular}{|c|c|c|c|c|c|c|}
\hline \multirow{2}{*}{ Reason } & \multicolumn{5}{|c|}{ Province } & \multirow{2}{*}{$\begin{array}{c}\text { Research } \\
\text { area }\end{array}$} \\
\hline & Edirne & Kirklareli & Tekirdag & Istanbul & Çanakkale & \\
\hline Higher seed yield potential & 53 & 30 & 75 & 3 & 12 & 173 \\
\hline Resistance to broomrape & 62 & 16 & 42 & 1 & 6 & 127 \\
\hline Easy availability on the market & 0 & 0 & 10 & 0 & 0 & 10 \\
\hline Easy weed control & 0 & 0 & 6 & 1 & 0 & 7 \\
\hline Higher oil content & 8 & 13 & 42 & 0 & 3 & 66 \\
\hline Other reasons & 7 & 2 & 7 & 0 & 0 & 16 \\
\hline
\end{tabular}

Further, $67.50 \%$ of the farmers (54 growers) indicated that they chose NRH cultivars due to their higher yield potential (Table 3 ). The second most cited factor 
(25\%, 20 growers) were other reasons. On the other hand, easy weed control and higher yield potential were the most important factors affecting the farmers' choice of sunflower cultivars.

Table 3: Reasons for choosing NRH sunflower cultivars

\begin{tabular}{lcccccc}
\hline \multirow{2}{*}{ Reason } & \multicolumn{7}{c}{ Province } & $\begin{array}{c}\text { Research } \\
\text { area }\end{array}$ \\
\cline { 2 - 6 } & Edirne & Kirklareli & Tekirdag & Istanbul & Çanakkale & (24 \\
\hline Higher seed yield potential & 7 & 22 & 0 & 1 & 54 \\
Resistance to broomrape & 1 & 0 & 1 & 0 & 0 & 2 \\
Easy finding in the market & 1 & 0 & 0 & 0 & 0 & 1 \\
Easy weed control & 0 & 0 & 2 & 0 & 0 & 2 \\
Higher oil content & 0 & 2 & 2 & 1 & 0 & 5 \\
Other reasons & 6 & 6 & 6 & 0 & 2 & 20 \\
\hline
\end{tabular}

\section{THE DIFFERENCE ANALYSIS AMONG SUNFLOWER HYBRID GROUPS}

\section{Seed yield differences}

The differences among the groups in seed yield were found to be statistically significant at the $5 \%$ level (Table 4). Seed yields of the different sunflower groups were found to be as follows: IMIH cultivars - 1,694.0 $\mathrm{kg} \mathrm{ha}^{-1}$; GRH cultivars $1,928.4 \mathrm{~kg} \mathrm{ha}^{-1}$; and NRH hybrids - 1,548.9 $\mathrm{kg} \mathrm{ha}^{-1}$.

Table 4: The ANOVA table among groups as regards seed yields

\begin{tabular}{lcccccc}
\hline \multirow{2}{*}{ Group } & \multirow{2}{*}{ Group } & $\begin{array}{c}\text { Mean } \\
\text { difference }(\mathrm{I}-\mathrm{J})\end{array}$ & $\begin{array}{c}\text { Std. } \\
\text { error }\end{array}$ & \multirow{2}{*}{ Sig. } & \multicolumn{2}{c}{ 95\% Confidence interval } \\
\cline { 6 - 7 } & & & & Lower bound & Upper bound \\
\hline \multirow{2}{*}{ IMIH } & GRH & $-234.32\left(^{*}\right)$ & 36.03 & 0.000 & -319.0 & -149.69 \\
& $\mathrm{NRH}$ & $145.11\left(^{*}\right)$ & 61.12 & 0.047 & 1.54 & 288.69 \\
GRH & $\mathrm{NRH}$ & $379.44\left(^{*}\right)$ & 60.36 & 0.000 & 237.67 & 521.21 \\
\hline
\end{tabular}

* Mean difference significant at the 0.05 level

\section{Differences in revenue obtained per hectare}

Based on the statistical analysis of revenue obtained per ha, the differences among hybrid groups were found to be statistically significant at the $5 \%$ level (Table 5 ). Seed yields of the sunflower groups were as follows: IMIH cultivars - 783.4 US\$ ha $^{-1}$; GRH cultivars - 888.1 US\$ ha ${ }^{-1}$; and NRH cultivars - 713.5 US\$ ha-1.

Table 5: The ANOVA table among groups as regards revenue per ha

\begin{tabular}{llccccc}
\hline \multirow{2}{*}{ Group } & \multirow{2}{*}{ Group } & $\begin{array}{c}\text { Mean } \\
\text { difference }(\mathrm{I}-\mathrm{J})\end{array}$ & $\begin{array}{c}\text { Std. } \\
\text { error }\end{array}$ & Sig. & \multicolumn{2}{c}{ 95\% Confidence interval } \\
\cline { 6 - 7 } & & & & Lower bound & Upper bound \\
\hline \multirow{2}{*}{ IMRH } & GRH & $-104.77\left(^{\star}\right)$ & 17.07 & 0.000 & -144.81 & -64.63 \\
& NRH & $69.90\left(^{*}\right)$ & 28.95 & 0.042 & 1.93 & 137.94 \\
GRH & NRH & $174.66\left(^{*}\right)$ & 28.59 & 0.000 & 107.51 & 241.81 \\
\hline
\end{tabular}

* Mean difference significant at the 0.05 level 


\section{Differences in the amount of hybrid seed used per hectare}

All differences among the groups in seed yield were found to be statistically significant at the 5\% level except for the difference between IMIH cultivars and NRH cultivars (Table 6).

Table 6: The ANOVA table among groups as regards seed amount used per ha

\begin{tabular}{|c|c|c|c|c|c|c|}
\hline \multirow{2}{*}{ Group } & \multirow{2}{*}{ Group } & \multirow{2}{*}{$\begin{array}{c}\text { Mean } \\
\text { difference (I-J) }\end{array}$} & \multirow{2}{*}{$\begin{array}{l}\text { Std. } \\
\text { error }\end{array}$} & \multirow{2}{*}{ Sig. } & \multicolumn{2}{|c|}{ 95\% Confidence interval } \\
\hline & & & & & Lower bound & Upper bound \\
\hline \multirow{2}{*}{$\mathrm{IMIH}$} & GRH & $108.35\left(^{*}\right)$ & 32.96 & 0.003 & 30.90 & 185.80 \\
\hline & $\mathrm{NRH}$ & -40.19 & 55.95 & 0.753 & -171.60 & 91.20 \\
\hline GRH & $\mathrm{NRH}$ & $-148.54(*)$ & 55.27 & 0.020 & -278.40 & -18.70 \\
\hline
\end{tabular}

* Mean difference significant at the 0.05 level

Seed yields of the sunflower groups were determined to be as follows: IMIH cultivars - 3,786.7 $\mathrm{kg} \mathrm{ha}^{-1}$; GRH cultivars - 3,678.4 $\mathrm{kg} \mathrm{ha}^{-1}$, and NRH - cultivars $3,826.9 \mathrm{~kg} \mathrm{ha}^{-1}$.

\section{ADOPTION SITUATION OF SUNFLOWER HYBRIDS BY GROUP}

\section{Adoption degree}

The highest rate $(51.01 \%)$ was obtained from IMIH cultivars in the sunflowerproducing enterprises in the region. The rates were $41.58 \%$ for GRH cultivars and $7.41 \%$ for NRH cultivars (Table 7 ).

Table 7: The adoption degree of sunflower cultivar in the provinces (\%)

\begin{tabular}{lcccc}
\hline Province & Total area planted to sunflower & IMIH Areas & GRH Areas & NRH Areas \\
\cline { 2 - 5 } & $($ ha) & $(\%)$ & $(\%)$ & $(\%)$ \\
\hline Edirne & $1,176.00$ & 34.46 & 59.85 & 5.70 \\
Canakkale & 139.50 & 6.81 & 84.59 & 8.60 \\
Istanbul & 295.30 & 94.14 & 5.86 & 0.00 \\
Tekirdag & $2,430.55$ & 50.96 & 42.32 & 6.72 \\
Kirklareli & $1,308.40$ & 60.98 & 27.26 & 11.76 \\
\hline Total & 5349.75 & 51.01 & 41.58 & 7.41 \\
\hline
\end{tabular}

\section{Adoption rate}

The GRH cultivars ranked first (49.46\%) in terms of the adoption rates in the research. IMIH cultivars were second with $40.88 \%$, followed by NRH cultivars with $9.65 \%$ (Table 8 ). These results support those of Kaya et al., (2009) indicating that over $90 \%$ of the sunflower areas in the Thrace region were infested with new broom- 
rape races and that broomrape and weed control were the main factors in sunflower production.

Table 8: The adoption degree of sunflower cultivar in the provinces (\%)

\begin{tabular}{lcccc}
\hline \multirow{2}{*}{ Province } & $\begin{array}{c}\text { Total number of fields } \\
\text { per enterprise }\end{array}$ & IMIH & GRH & NRH \\
\cline { 2 - 5 } & (number) & $(\%)$ & $(\%)$ & $(\%)$ \\
\hline Edirne & 214 & 63.08 & 30.37 & 6.54 \\
Canakkale & 26 & 80.77 & 11.54 & 7.69 \\
Istanbul & 29 & 13.79 & 86.21 & 0.00 \\
Tekirdag & 295 & 51.53 & 38.98 & 9.49 \\
Kirklareli & 182 & 31.32 & 53.30 & 15.38 \\
\hline Total & 746 & 49.46 & 40.88 & 9.65 \\
\hline
\end{tabular}

\section{The adoption intensity}

IMI hybrids had the highest adoption intensity (20.86\%) in the research. GRH and IMI hybrids had similar rates, while NR hybrids had much lower rates based on the adoption intensity in the study (Table 9). On the other hand, the Istanbul province had the highest adoption intensity and rate due to all the weed control made by IMI herbicides, the higher cost of weed control by hoeing in sunflower production, higher worker costs, difficulties in finding workers, and having larger fields in the area.

Table 9: The adoption intensity of sunflower cultivar in the provinces (\%)

\begin{tabular}{lccc}
\hline Province & $\mathrm{IMIH}(\%)$ & $\mathrm{GRH}(\%)$ & $\mathrm{NRH}(\%)$ \\
\hline Edirne & 10.47 & 37.75 & 0.37 \\
Canakkale & 0.79 & 68.32 & 0.66 \\
Istanbul & 81.16 & 0.81 & 0.00 \\
Tekirdag & 19.86 & 21.81 & 0.64 \\
Kirklareli & 32.50 & 8.54 & 1.81 \\
\hline Total & 20.86 & 20.57 & 0.71 \\
\hline
\end{tabular}

\section{CONCLUSIONS}

The rate of sunflower production area was $42.73 \%$ of total agricultural land in the region. Furthermore, the rate of sunflower revenue in total agricultural income was $22.71 \%$.

The research results indicated that seed yields of $\mathrm{NRH}$ cultivars (1610.60 kg ha-1) were lower than those of IMIH cultivars $\left(1,915.30 \mathrm{~kg}^{-1}\right.$ ) and GRH cultivars $\left(1,915.30 \mathrm{~kg} \mathrm{ha}^{-1}\right)$ in the agricultural enterprises in the region. The adoption degree of IMIH cultivars (51.01\%) was higher than that of GRH cultivars $(41.58 \%)$ in the research area. However, GRH cultivars $(49.46 \%)$ were above the other sunflower groups based on the adoption rate. 
The most important factors affecting farmers' decisions were easy weed control with IMI herbicide for IMIH cultivars and high seed yield potential for GRH and NRH cultivars. The differences based on seed yield per ha, revenue, and seed used per ha were significant among the sunflower cultivars in the research. The most profitable sunflower cultivars were GR hybrids. However, the farmers obtained more net profit from NRH cultivars than from IMIH cultivars.

Our research results indicate that agricultural enterprises should consider and choose very carefully the sunflower cultivars which they will plant in their fields due to most of the planted areas (over 90\%) being infested by broomrape. Furthermore, the farmers should also choose and plant sunflower hybrids having a higher oil content in order to get more profit, and the increased proportion of higher oil content in the market will help reduce the oil seed deficit in Turkey. On the other hand, based on this situation in the region, sunflower breeders should focus mainly in their breeding programs on the development of sunflower hybrids that have higher seed yields and oil content and are broomrape resistant.

\section{REFERENCES}

Erkan, O. and Cicek, A., 1996. Tarim Ekonomisinde Araştirma ve Ornekleme Yontemleri. GOP Un. Z. F. Yay. No12: 6. Tokat. Turkey.

Erkus, A. and Demirci, R., 2007. Tarimsal Isletmecilik ve Planlama. Ankara Un. Ziraat Fak. Yay No.1435. Ders Kitabi No. 417, pp. 31-39. Ankara. Turkey.

FAO. 2009. Agricultural Statistical Database (www.fao.org).

Green, S.B., Salkind, N.J., Akey, T.M., 2000. Using SPSS For Windows, Analyzing and Understanding Data, Second Edition, Prentice-Hall, Inc., Upper Saddle River, New Jersey, USA.

Kaya, Y., Evci, G., Pekcan, V., Gucer, T., Yilmaz, I.M., 2009. The Evaluation of Broomrape Resistance in Sunflower hybrids. Helia 32(51): 161-170.

Mazid, A., Amegbeto, K.N., Keser, M., Morgounav, A., Peker, K., Bagci, A., Akin, M., Kucukcongar, M., Kan. M., Karabak, S., Semerci, A., Altikat, A., Yaktubay, S., 2009. Adoption and Impacts of Improved Wheat Varieties in Turkey. ICARDA. p. 21. Aleppo, Syria.

Shideed, K.H. and El Mourid, M., 2005. Adoption and impact assessment of improved technologies in crop and livestock production system in the WANA region. p.10. International center for agricultural research in the dry areas. ICARDA. Aleppo, Syria.

TUIK. 2009. Bitkisel Uretim Verileri. (www.tuik.gov.tr).

Ural, A. and Kilic, I., 2006. Bilimsel Arastirma Sureci ve SPSS ile Veri Analizi. Detay Yayincilik. No.113: 213-218. Ankara.

Yemane, T., 1967. Elemantory Sampling Theory. Prentice-Hall Inc. Englowood Cliffs, N. Jersey, USA. 